\title{
17-Beta-Hydroxysteroid Dehydrogenase 3 Deficiency
}

National Cancer Institute

\section{Source}

National Cancer Institute. 17-Beta-Hydroxysteroid Dehydrogenase 3 Deficiency. NCI

Thesaurus. Code C120203.

Decreased activity of the steroidogenic enzyme, 17-beta-hydroxysteroid

dehydrogenase, associated with mutation(s) in the HSD17B3 gene, leading to reduced testosterone production. 